\title{
Penerapan Bahan Ajar Dalam Peningkatan Kemampuan Kognitif Peserta Pelatihan Tata Kecantikan Kulit di LKP Piesca Jember
}

\author{
Renita Swasti, Niswatul Imsiyah , Lutfi Ariefianto \\ Pendidikan Luar Sekolah, Universitas Jember. Jl. Kalimantan No. 37, Tegal Boto, Jember 62811, Indonesia \\ Email : renitaswasti96@gmail.com,niswatul@unej.ac.id
}

\begin{abstract}
Abstrak
LKP Piesca merupakan satu-satunya lembaga yang memiliki TUK (Tempat Uji Kompetensi) di bidang tata kecantikan kulit. Pada pembelajarannya lebih mengutamakan praktek, hal ini harus diimbangi dengan bahan ajar modul sehingga warga belajar dapat belajar secara komprehensif. Penelitian ini merupakan penelitian deskriptif. Teknik pengumpulan data yaitu teknik observasi, teknik wawancara, dan teknik dokumentasi. Teknik penentuan informan penelitian dalam penelitian ini menggunakan snowball sampling, dimana instruktur dan beberapa peserta pelatihan tata kecantikan kulit sebagai informan kunci dan pengelola lembaga sebagai informan pendukung. Teknik keabsahan menggunakan perpanjangan pengamatan, triangulasi sumber dan triangulasi teknik. Analisis data menggunakan model Miles and Huberman dengan langkah-langkah yaitu reduksi data, penyajian data, dan penarikan kesimpulan. Hasil dari penelitian ini yaitu bahan ajar yang diberikan sudah relevan, cukup, dan sesuai dengan Standar Kompetensi. penyampain bahan ajar yang dilakukan oleh instruktur mudah difahami oleh peserta pelatihan. Sehingga dapat meningkatkan kemapuan konitif yaitu peserta pelatihan mampu mengingat, memahami, serta menerapkan apa yang telah diajarkan oleh instruktur. Bahkan ada peserta pelatihan yang sudah bisa membuka salon kecantikan sendiri. Kesimpulan dari penelitian ini yaitu bahan ajar di LKP Piesca mampu meningkatkan kemampuan kognitif peserta pelatihan.
\end{abstract}

Kata Kunci: penerapan bahan ajar, pelatihan tata kecantikan kulit, kemampuan kognitif.

\section{The Application of Teaching Instruments for Enhancing the Cognitive Abilities of Skin Beauty Trainees at LKP Piesca Jember}

\begin{abstract}
LKP Piesca is the only institution that has a TUK ( Tempat Uji komepetensi) in the field of skin beauty. In learning that prioritizes practice, this must be balanced with teaching modules so that learning citizens can comprehensive learn. This research is a descriptive study. Data collection techniques namely observation techniques, interview techniques, and documentation techniques. The technique of determining the research informants in this study used snowball sampling, in which the instructor and several students of skin beauty were the key informants and the agency manager as the supporting informants. Data validity techniques are the extension of observation, source triangulation and technique triangulation. Data analysis in the field uses the Miles and Huberman model with steps such as data reduction, data presentation, and drawing conclusions. The results of this study are the teaching materials provided are relevant, sufficient, and in accordance to Standards Competency. the delivery of teaching materials by the instructor is easily understood by the students. So that it can improve the positive capabilities of the students to remember, understand, and apply what has been taught by the instructor. There are even students who can open their own beauty salon. The conclusion of this study is teaching materials at LKP Piesca can improve the cognitive abilities of trainees.
\end{abstract}

Keywords: Application of theacing materials, Skin beauty training, cognitive ability. 


\section{Learning Community: Jurnal Pendidikan Luar Sekolah, 4 (1), Maret 2020 - 2}

Renita Swasti

\section{PENDAHULUAN}

Menurut UU No. 20 tahun 2003 tentang Pendidikan Nasional. Secara umum dalam pasal 26 ayat (5) dijelaskan bahwa kursus dan pelatihan diselenggarakan bagi masyarakat yang memerlukan bekal pengetahuan, keterampilan, kecakapan hidup, dan sikap untuk mengembangkan diri, mengembangkan profesi, bekerja, usaha mandiri, dan/atau melanjutkan pendidikan kejenjang yang lebih tinggi, salah satunya yaitu Lembaga Kursus dan Pelatihan PIESCA Jember.

LKP PIESCA Jember merupakan salah satu lembaga kursus dan pelatihan yang berkembang di Kabupaten Jember yang beralamat di Jl. Karimata No. 04, Sumbersari, Kec. Sumbersari, Kab. Jember. LKP PIESCA sendiri merupakan satu-satunya lembaga yang memiliki TUK (Tempat Uji Kompetensi ) di bidang tata kecantikan kulit. LKP PIESCA menunjukkan bahwa dalam beberapa tahun terakhir ini banyak dari kalangan masyarakat yang berminat mengikuti kursus dan pelatihan tata kecantikan kulit. Dengan adanya hal tersebut menjadikan banyak masyarakat yang berminat untuk membuka usaha mandiri di bidang tata kecantikan kulit. Tentunya dalam proses pembelajaran pelatihan ini menggunakan bahan ajar untuk mendukung tercapainya suatu pembelajaran.

Bahan ajar adalah segala bentuk bahan, informasi, alat dan teks yang digunakan ntuk membantu guru/instruktur dalam melaksanakan kegiatan belajar mengajar (Majid, 2007 :174). Pedoman bagi instruktur dan peserta pelatihan dalam mengarahkan aktifitas dalam proses pembelajaran suatu pelatihan untuk mencapai tingkat kreativitas, perlu diterapkan beberapa prinsip bahan aja yaitu prinsip relevansi, konsistensi, dan kecukupan (Hidayat, 2013 : 62). Dengan adanya bahan ajar sesuai prinsip-prinsip bahan ajar tersebut, diharapan agar dapat menjadi alternatif bagi pendidik maupun peserta didik dalam memudahkan proses pembelajaran. Bahan ajar tersebut dapat membantu meningatkan kemampuan kognitif masyarakat mengenai tata kecantikan kulit, dengan bisa membandingkan yang awalnya mereka hanya tahu sekedarnya mengenai tata kecantikan kulit, yang akhirnya menjadikan mereka faham bagaimana cara melakukan dan mengaplikasikan proses tata kecantikan kulit yang benar.

Taksonomi Bloom ranah kognitif yang telah direvisi Anderson dan Krathwohl (2001:66-88) yakni: mengingat (remember), memahami/mengerti (understanding), menerapkan (applying), menganalisis (analyze), mengevaluasi (evaluate), dan menciptakan (create). Peserta didik bisa di katakan kemampuan kognitifnya meningkat apabila dapat mengingat, memahami, serta dapat menerapkan apa yang telah di ajarkan oleh tutor/pendidik. Ada beberapa komponen yang dapat mendukung tercapainya peningkatan kemampuan kognitif dalam pebelajaran, salah satunya yaitu bahan ajar. Akan tetapi, pada kenyataannya di lapangan tidak sesuai dengan yang diharapkan. Masalah yang dihadapi ialah peserta didik tidak begitu menggunakan bahan ajar modul dengan maksimal. Mereka lebih memilih pembelajaran praktek, tapi tidak diimbangi dengan bahan ajar modul sehingga mereka terkadang sering lupa mengenai langkahlangkah yang harus dilakukan sesuai prosedur. Instrukturnya sendiri hanya menjelaskan teori bersamaan dengan proses praktek tersebut. Sehingga kurang efektif dalam proses pembelajaran teori. Padahal teori ini harus dikuasai peserta didik guna dapat menjawab pada saat uji kompetensi mengenai teori tata kencantikan kulit nantinya. Tentunya hal ini berkaitan dengan penerapan bahan ajar yang mungkin kurang sesuai.

Sehingga rumusan masalah pada penelitian ini yaitu bagaimana penerapan bahan ajar dalam peningkatan kemampuan kognitif peserta pelatihan tata kecantikan kulit di LKP Piesca Jember. Adapun tujuan dari penelitian ini yaitu untuk mengetahui untuk mengetahui penerapan bahan ajar dalam peningkatan kemampuan kognitif peserta pelatihan tata kecantikan kulit di LKP Piesca Jember.

\section{METODE}

Jenis penelitian yaitu penelitian deskriptif dengan pendekatan kualitatif. Lokasi penelitian ditentukan dengan metode purposive area dengan teknik pengumpulan data yaitu teknik observasi partisipatif, 


\section{Learning Community: Jurnal Pendidikan Luar Sekolah, 4 (1), Maret 2020 - 3}

Renita Swasti

teknik wawancarasemi-struktur, teknik dokumentasi. Teknik penentuan informan dalam penelitian ini yaitu menggunakan snowball sampling. Snowball sampling merupakan teknik penentuan yang awal mulanya sedikit, lalu membesar jika masih dirasa data yang dibutuhkan belum mencukupi (Sugiyono, 2016:85). Teknik keabsahan data yang diterapkan dalam penelitian ini yaitu menggunakan perpanjangan pengamatan, keikutsertaan ketekunan pengamatan, serta triangulasi sumber dan triangulasi teknik. Analisis data di lapangan pada penelitian ini menggunakan model Miles and Huberman dengan menggunakan langkah-langkah sebagai berikut :

a. Pengumpulan data, analisis data model pertama dilakukan pengumpulan data menggunakan hasil observasi, hasil wawancara, dan hasil dokumentasi berdasarkan masalah yang diteliti oleh peneliti di lapangan yang kemudian dikembangkan penajaman data melalui pencarian data selanjutnya.

b. Reduksi data, merangkum, memilih halhal pokok, serta memfokuskan pada jalhal yang penting selama proses penelitian. Dengan begitu maka akan diperoleh data yang lebih jelas, dan mempermudah peneliti untuk melakukan pengumpulan data selanjutnya.

c. Penyajian data, Dalam penyajian data bisa dilakukan dalam berbagai bentuk seperti uraian singkat, bagan, hubungan antar katagori, flowchart. Penyajian data digunakan peneliti untuk mengecek sejauh mana pemahamannya.

d. Verifikasi data, merupakan kesimpulan awal yang bersifat sementara, dan dapat berubah jika ditemukan bukti-bukti yang kuat dan mendukung pada sat pengumpulan data. Namun apabila kesimpulan yang dilakukan di tahap awal sudah didukung oleh bukti-bukti yang valid dan konsisten saat peneliti kembali ke lapangan maka kesimpulan tersebut diyatakan akurat.

\section{HASIL DAN PEMBAHASAN}

Berdasarkan analisis data yang telah dilakukan peneliti menunjukkan bahwa penerapan bahan ajar dalam pelatihan tata kecantikan kulit memberikan peningkatan kemampuan kognitif pada peserta pelatihan di LKP Piesca Jember.

Bahan ajar merupakan modal awal yang akan digunakan untuk mencapai hasil berupa pemahaman dan kemampuan. Bahan ajar disusun guna menunjang proses pembelajaran sesuai dengan kebutuhan pembelajaran. Menurut Majid (2007: 173) Melalui bahan ajar memungkinkan peserta pelatihan dapat mempelajari suatu kompetensi atau kompetensi dasar secara runtut dan sistematis sehingga secara akumulatif mampu menguasai semua kompetensi secara utuh dan terpadu. Bahan ajar yang diberikan di LKP Piesca sudah memenuhi 3 prinsip bahan ajar, yaitu prinsip relvansi, prinsip konsistensi dan prinsip kecukupan menurut Sukamadinata (2009:144).

Prinsip relevansi yaitu adanya keterkaitan antara bahan ajar yang diberikan di LKP Piesca dengan SKL. akan tetapi dalam proses pembelajarannya LKP Piesca mempunyai system sendiri yaitu instruktur memberikan materi di sela-sela praktek dengan harapan agar peserta pelatihan lebih mudah memahami apa yang telah diajarkan oleh instruktur. Dengan adanya bahan ajar yang relevan dapat memudahkan peserta pelatihan dalam mengingat apa yang telah di ajarkan.

Sesuai dengan peningkatan kemampuan kognitif dalam hal mengingat (remember), dengan adanya bahan ajar yang relevan atau adanya keterkaitan antara modul dengan SKL membuat peserta pelatihan mendapatkan kembali pengetahuan dari memori atau ingatan yang telah lampau, baik yang baru saja didapatkan maupun yang telah lama didapatkan. Kadang juga ditambahi dengan cara merekam dalam bentuk video mengenai step by step pada saat praktek, ada juga dengan cara mengulang-ulang praktek di rumah dengan menggunakan keluarganya sendiri sebagai model untuk praktek.

Sedangkan dalam hal memahami dan mengerti (understand) peserta pelatihan kurang dapat memahami jika hanya dari bahan ajar seperti modul yang diberikan tersebut. Peserta pelatihan lebih mudah memahami ketika pada proses pembelajaran 


\section{Learning Community: Jurnal Pendidikan Luar Sekolah, 4 (1), Maret 2020 - 4}

Renita Swasti

praktek. Karena kembali lagi pada latar belakang mereka yaitu rata-rata ibu-ibu yang memiliki SDM rendah, jadi mereka lebih mudah memahami yang telah diajarkan melalui praktek. Akan tetapi pada saat praktekpun instuktur tetap memberikan pembelajaran materi di sela sela praktek.

Namun dalam hal memerapkan (apply) bahan ajar tidak begitu digunakan, karena para peserta pelatihan lebih memilih pembelajaran pada saat praktek. Dalam bahan ajar yang telah dijelaskan di dalam modul berisi tentang step by step yang harus diterapkan pada proses pengaplikasiannya. Akan tetapi dalam hal menerapkan pada saat di lapangan mereka lebih mengutamakan kepuasan pelanggan. Maka mereka lebih menerapkan apa yang telah diajrakan pada saat praktek. Karena pada saat praktek diajarkan bagaimana cara memfacial wajah sesuai dengan kebutuhan pelanggan. Jadi bahan ajar yang diberikan di LKP Piesca hanya digunakan dalam menghadapi ujian kompetensi saja.

Berdasarkan paparan di atas dapat dikatakan bahwa bahan ajar yang terdapat di LKP Piesca pada prinsip relevansi mampu meningkatkan kemampuan kognitif peserta pelatihan. Walaupun dalam proses penerapannya lebih banyak menggunakan pembelajaran pada saat prakteknya. Di lihat lagi dari tujuan pelatihan ini yaitu untuk memberikan skill pada peserta pelatihan ketika nantinya terjun di dunia pekerjaan. Karena di dunia pekerjan yang diharapkan yaitu kepuasan pelanggan.

Pada prinsip konsistensi adalah ketataasazan (keajegan) dalam penyusunan bahan ajar, misalnya seperti kompetensi dasar meminta kemampuan peserta didik untuk menguasai 3 macam konsep maka materi bahan ajar yang disajikan juga 3 macam, artinya apa yang diminta itulah yang diberikan (Zulfikarnaini,2009). Disini bahan ajar yang diberikan sudah konsisten antara modul yang telah tersaji dengan pemberian materi dan prakteknya. Bahan ajar yang ditemukan peneliti saat di lapangan yaitu modul 1 mengenai perawatan kulit wajah (facial), modul 2 mengenai tata rias wajah sehari-hari (make up), modul 3 mengenai perawatan tangan, kaki dan rias kuku (manicure pedicure), daftar perlengkapan alat-alat untuk praktek, panduan dalam bentuk gambar disetiap prakteknya serta contoh soal-soal uji kompetensi. dengan adanya konsistensi dalam pemberian bahan ajar, maka dapat memudahkan peserta pelatihan dalam menerapkan apa yang telah diberikan selama proses pembelajaran.

Dengan adanya bahan ajar yang konsiten dapat meningkatkan kemampuan kognitif peserta pelatihan dalam hal mengingat (remember). Bahan ajar yang diberikan secara urut, tertata dan ajeg sesuai dengan standar kompetensi sehingga dapat memudahkan peserta pelatihan untuk mendapatkan kembali pengetahuan dari memori yang telah lampau maupun yang baru saja didapatkan. Misalnya yang dibutuhkan oleh peserta pelatihan ada 3 yaitu facial, make up dan many pedy maka yang disediakan pada bahan ajar 3 hal tersebut.

Pada peningkatan kemampuan kognitif memahami (understand), bahan ajar yang ada di LKP Piesca dapat mempermudah peserta pelatihan dalam memahami bahan ajar. karena bahan ajar yang disajikan di LKP Piesca sudah sesuai dengan SKL. Dalam penyampaian materi, instruktur menyampaikannya dengan detail dan fokus pada yang diajarkan. Misalnya mengenai facial wajah, maka intruktur akan mengajarkan mulai dari kosmetik apa saja yang digunakan, cara memijat pada wajah, cara mengaplikasikan masker wajahsampai dengan selesai.

Sesuai dengan peningkatan kemampuan kognitif yaitu menerapkan (Apply) , dengan adanya pemberian bahan ajar yang konsisten dapat membuat peserta pelatihan belajar dengan konsisten apa yang telah di dapat selama pelatihan berlangsung. Sehingga pada saat peseta pelatihan terjun di lapangan dapat menerapkan apa yang telah diajarkan sesuai dengan prosedur telah diajarkan. Menjalankan prosedur disini ketika peserta pelatihan mampu menyelesaikan masalah dan melaksanakan percobaan dimana peserta pelatihan sebelumnya sudah mengetahui informasi tersebut. Misalnya peserta pelatihan memiliki pelanggan facial wajah yang memiliki kulit yang berminyak, maka peserta pelatihan tersebut menggunakan milk cleancer dan toner mentimun agar dapat mengurangi minyak berlebih pada kulit wajah. 


\section{Learning Community: Jurnal Pendidikan Luar Sekolah, 4 (1), Maret 2020 - 5}

Renita Swasti

Dari paparan di atas, dapat disimpulkan bahwa bahan ajar yang konsisiten di LKP Piesca dapat meningkatkan kemampuan kognitif peserta pelatihan dalam hal mengerti, memahami dan menerapkan pada saat di lapangan. Bahan ajar yang konsiten dalam pemberiannya dapat mempermudah peserta pelatihan dalam menerima pembelajaran. Karena jika bahan ajar yang diberikan tidak konsisten, misalnya penyampain materi harusnya mengenai facial wajah, namun pada saat materi mengenai facial wajah belum selesai tiba-tiba ganti ke materi make up, hal seperti itu akan menyulitkan peserta pelatihan dalam memahami materi yang diberikan tersebut.

Pada prinsip kecukupan disini diartikan bahwa bahan ajar yang diberikan di LKP Piesca sudah cukup, tidak kurang dan tidak lebih. Bahan ajar yang diberikan dibuat sesuai dengan Kompetensi dasar dan juga penyampaiannya sesuai dengan kemampuan peserta pelatihan. Dengan adanya bahan ajar yang cukup dapat mempermudah peserta pelatihan untuk memahami apa yang telah diajarkan.

Dengan adanya bahan ajar yang cukup dapat membuat peserta pelatihan meningkatkan kemampuan kognitif mengingat (remember), pemberian bahan ajar di LKP Piesca ditentukan sesuai dengan Standar Kompetisi dan kebutuhan peserta pelatihan. Jika peserta pelatihan mengalami kesulitan dalam mengingat apa yang telah dipaparkan pada bahan ajar, maka pihak LKP dan instruktur memberikan penjelasan menggunakan bahasa yang mudah difahami oleh mereka. Sehingga peseta pelatihan mampu mengingat apa yang telah diajarkan pada proses pelatihan tersebut

Sesuai dengan peningkatan kemampuan kognitif dalam hal memahami/ mengerti (understand), maka dengan adanya bahan ajar yang cukup yaitu tidak kurang dan tidak lebih dapat membuat peserta pelatihan memahami apa yang telah di ajarkan. Hasil temuan penelitian melalui wawancara dan observasi yang dilakukan peneliti di LKP Piesca menunjukkan bahwa dengan adanya bahan ajar yang cukup membuat peserta pelatihan mampu memahami dan mengerti mengenai anatomi kulit, cara memfacial yang benar, cara menggunakan make up yang benar, serta dapat melakukan perawatan pada kuku. Peserta pelatihan juga mampu menyatukan antara pengetahuan mengenai tata kecantikan sebelum mengikuti pelatihan dengan setelah mengikuti pelatihan. Mereka juga dapat menerima apa yang telah diajarkan oleh instruktur, bahwa semua yang dilakukan selama ini mengenai tata kecantikan kulit tidak semua benar dan tidak semua salah.

Pada peningkatan kemampuan kognitif menerapkan (aplly) bahan ajar yang diberikan di LKP Piesca sudah cukup, sehingga dapat membantu peserta pelatihan dalam proses penerapan pada saat di lapangan. Bahan ajar yang cukup tidak kurang dan tidak lebih mampu membuat peserta mengingat dan memahami apa yang telah diajarkan, sehingga peserta pelatihan dapat menerapkan ketika di lapangan. Walaupun awalnya masih kaku da nada beberapa bagian yang lupa atau terlewatkan. Namun dengan cara mengulang-ngulang pembelajaran dan pratek membuat peserta pelatihan dapat menerapkan apa yang telah diajarkan bahkan mampu mengatasi ketika ada masalah di lapangan. Misalnya cara make up untuk wajah yang berjerawat parah, maupun wajah yang ada cacat akibat kecelakaan maupun bawaan dari lahir.

Berdasarkan paparan di atas dapat disimpulkan bahwa bahan ajar yang ada di LKP Piesca sudah cukup untuk menunjang peningkatan kemampuan kognitif dalam mengingat, memahami dan menerapkan oleh peserta pelatihan tata kecantikan kulit. bahan ajar tersebut sudah sesuai dengan SKL dan kebutuhan peserta pelatihan dengan takaran yang pas, tidak kurang dan tidak lebih. Kalaupun ada peserta pelatihan yang merasa merasa kesusahan dalam memahami maka instruktur menjelaskan dengan bahasa yang mudah dipahami oleh peserta pelatihan. Sehingga tidak ada hambatan lagi bagi peserta pelatihan dalam meningkatkan kemampuan kognitifnya.

\section{SIMPULAN}

Berdasarkan analisis data maka dapat disimpulkan bahwa penerapan bahan ajar selama proses pembelajaran pelatihan tata kecantikan kulit di LKP Piesca Jember, bahwa bahan ajar yang diberikan sudah sesuai dengan Standar Kompetensi Lulusan (SKL) dan kompetensi dasar. Pada proses 


\section{Learning Community: Jurnal Pendidikan Luar Sekolah, 4 (1), Maret 2020 - 6 Renita Swasti}

pembelajarannya pengelola lembaga serta instruktur membuat system sendiri untuk pembelajarannya, akan tetapi masih sesuai dengan SKL yang ada. Dengan begitu bahan ajar yang diberikan dirasa sudah sesuai dengan prinsip kecukupan yang artinya bahan ajar yang diberikan tidak kurang dan tidak lebih serta mudah difahami oleh peserta pelatihan. Sehingga dengan penerapan bahan ajar yang relevansi, konsistensi, serta kecukupan dapat meningkatkan 3 aspek yaitu mengingat (remember), memahami atau mengerti (understand), dan menerapkan (apply). Pada kemampuan kognitif peserta pelatihan.

Berdasarkan ulasan di atas dapat diambil garis besar bahwa penerapan bahan ajar yang ada di LKP Piesca mampu meningkatkan kemampuan peserta pelatihan tata kecantikan kulit. Para peserta pelatihan memiliki ketrampilan baru setelah mengikuti pelatihan. Sehingga dapat digunakan untuk meningkatkan ekonomi dengan cara bekerja di bidang tata kecantikan kulit maupun dapat membuka salon kecantikan sendiri di rumah masing-masing peserta pelatihan yang telah dinyatakan lulus dan memiliki sertifikat.

\section{DAFTAR PUSTAKA}

Anderson, L.W., dan Krathwohl, D.R. 2001. A Taxonomy for Learning, Teaching, and Assesing: A Revision of Bloom's Taxonomy of Educatioanl ObjectiveNew York: Addison Wesley Longman, Inc.

Hidayat, Sholeh. 2013. Pengembangan Kurikulum Baru. Bandung: Remaja. Rosdakarya

Majid, A . (2007). Perencanaan Pembelajaran. Bandung: PT. Remaja. Rosdakarya

Sugiono.2016. Memahami Penelitian Kualitatif.Bandung : ALFABETA

Sukmadinata SN. 2009. Pengembangan Kurikulum Teori dan Praktek. Bandung:.

Zulkarnaini, Pembelajaran dengan Bahan Ajar Buatan Guru, hal. 5, 2009 nainidiran.wordpress.com/2009/06/28/ pembelajaran-dengan-bahan-ajarbuatan-guru/ 